\title{
Summary Report of China-UK Knowledge Exchange Project for Their Critical Zone Programme
}

\author{
Ying Zheng ${ }^{\mathrm{a}^{*}}$, Larissa A. Naylor ${ }^{\mathrm{a}}$, Susan Waldron ${ }^{\mathrm{a}}$, David M. Oliver ${ }^{\mathrm{b}}$

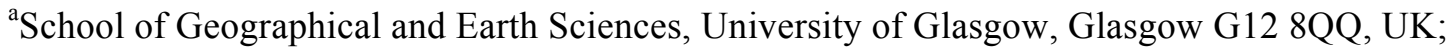 \\ ${ }^{\mathrm{b}}$ Faculty of Natural Sciences, University of Stirling, Stirling, FK9 4LA, UK \\ Contact: Ying Zheng (Ying.Zheng@glasgow.ac.uk)
}

\begin{abstract}
:
Global to local environmental policy-making is increasingly evidenced-based. Knowledge exchange (KE) is increasingly used by environmental scientists and policymakers, to deliver evidence-based policy and practice. This study presents the output from the KE research project within the China-UK Critical Zone (CZ) programme in China from 2016 to 2018, focussing on understanding: (i) the key issues of environmental management Chinese leaders and farmers face that our research can inform; (ii) the current ways in which they learn from scientists and their learning preference. To achieve this, surveys and interviews were conducted in two $\mathrm{CZ}$ research areas, from which we were able to assess stakeholders' preference for the types of KE practice.
\end{abstract}

This research showed that there was a need to create more communication opportunities for the local farmers and officials (from farm to county scale of governance) with scientists to improve their understanding of the landscapes they live in. This understanding allowed the development of a conceptual model of the science-policy-practice interface, and helped to understand how scientists can better engage with stakeholders to share knowledge more efficiently. Thus, suggestions are made for how KE can be implemented to ensure the underpinning CZ science research informs better the most challenging environmental and farming issues: i) how to improve water availability and quality; ii) how to reduce soil loss and enhance soil quality and iii) how to avoid unnecessary use of fertiliser.

This is a non-peer reviewed report published at EarthArXiv. 


\section{Table of Contents}

Project Aims

Funders

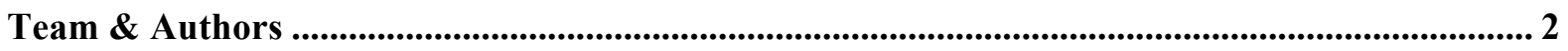

Acknowledgements ........................................................................................................................................ 2

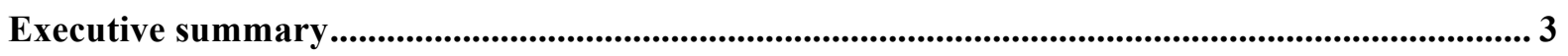

1. Rationales and aims of KE project in China-UK CZ programme ............................................ 7

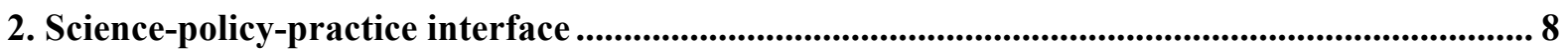

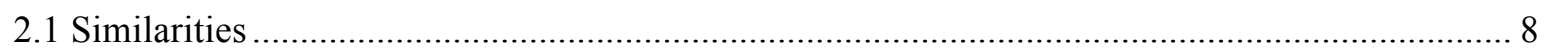

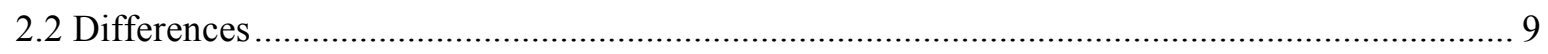

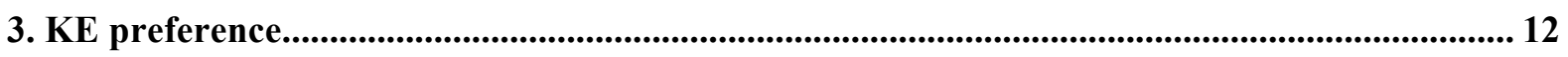

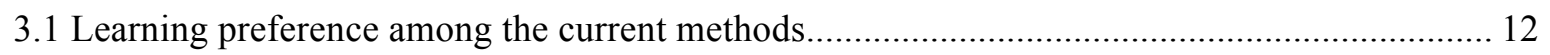

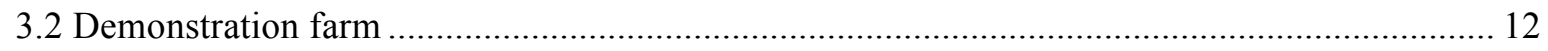

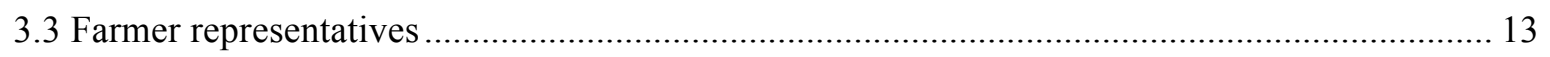

4. Suggestions for KE delivery in Yujiang \& Puding .................................................................. 14

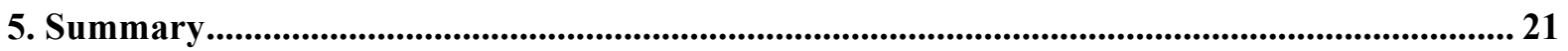

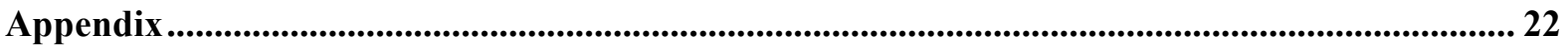

Question Area 1: Demographics and understanding about environment ...................................... 22

Question Area 2: Biggest challenges by farmers \& how to be more productive.............................. 23



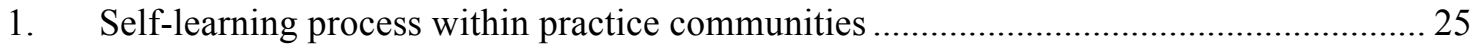

2. The farmer's perspectives on the value of learning from different groups....................... 26



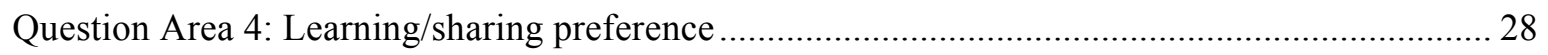

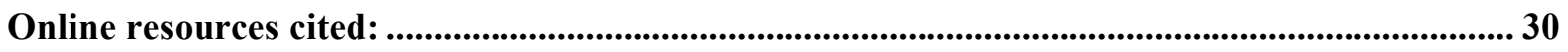




\section{Project Aims}

This research was undertaken for the China-UK Critical Zone (CZ) Project which comprises five research projects conducted in China during 2016-2018 inclusive to identify more sustainable land management practises. This study explores what knowledge transfer and knowledge exchange activities can facilitate communication and understanding between academics and the non-academic groups in these $\mathrm{CZ}$ research areas in the context of Chinese culture, especially in Chinese rural areas.

\section{Funders}

This publication was produced under grant NE/N007425/1 which was awarded by the UK Natural Environment Research Council (NERC), and through cooperation with grant 41571130074 awarded by the National Natural Science Foundation (NSFC) of China.

\section{Team \& Authors}

The UK KE project team consists of Prof. Susan Waldron (Principal Investigator), Dr. Larissa Naylor (co-Investigator) and Dr. Ying Zheng (KE associate) from the University of Glasgow, and Dr. David Oliver (co-Investigator) from the University of Stirling.

This publication is produced by Ying Zheng, Larissa A. Naylor, Susan Waldron and David M. Oliver. It can be cited as: Zheng, Y., Naylor, L.A., Waldron, S., Oliver, D.M. 2018. Summary Report of ChinaUK Knowledge Exchange Project for Their Critical Zone Programme. https://doi.org/10.17605/OSF.IO/9S23M.

Chinese Citation: 郑颖, Naylor, L.A., Waldron, S., Oliver, D.M. 2018. 中英关键带科学研究知识交 流项目总结报告. https://doi.org/10.17605/OSF.IO/9S23M.

\section{Acknowledgements}

The analysis draws on two surveys designed and led by the University of Glasgow team with ethics approval from the College of Science and Engineering, conducted in Puding, Guizhou and Yujiang, Jiangxi respectively.

The Puding survey was carried out with the help of Institute of Geochemistry Chinese Academy of Sciences (IGCAS), Puding Karst Ecosystem Research Station (P-KERS), and Anshun College in Guiyang. Prof. Shijie Wang and Dr. Tao Peng (both from P-KERS) provided valuable support in facilitating access to all groups surveyed: government departments, town and village leaders and local residents (farmers and non-farmers). Many government officers in the towns and villages helped to encourage their residents to complete the surveys and they also participated in the surveys themselves. Dr. Fujun Yue from University of Glasgow, students from IGCAS and staff from P-KERS helped us conduct the surveys providing practical and academic support.

The Yujiang survey was assisted by Institute of Soil Science, Chinese Academy of Sciences (ISSCAS), Yingtan Farmland Ecosystem National Field Observation and Research Station (hereafter shortened to Yingtan Station). Dr. Jianbo Fan, office director of Yingtan Station, provided significant support to help facilitate access to the local village leaders and residents surveyed. The local villager Qingtang Zhang and his friends provided great help to conduct the surveys with farmers in the villages. Dr. Lei Gao (ISSCAS), Dr. Joseph Oyesiku-Blakemore and Dr. Lucile Verrot (both from University of Aberdeen) provided helpful suggestion to refine the questionnaires. Dr. Lei Gao also helped prepare the survey, including advising the potential survey villages and introducing the local helpers. Many thanks also to Dr. Neil Munro and Dr. Nai Rui Chng from University of Glasgow, who provided valuable help in designing the Yujiang survey methods and advice in data analysis.

The undergraduate students of Anshun College and East China University of Technology greatly assisted in carrying out surveys with local farmers after receiving training from the UK researchers. They explained the survey aims and helped the local farmers complete the surveys. 


\section{Executive summary}

This report presents the output from the Knowledge Exchange research project within the China-UK Critical Zone (CZ) programme in China from 2016 to 2018, co-funded by NERC (UK) and NCSF (China). The project focused on understanding: (i) the current ways in which Chinese leaders, farmers and residents learn from scientists; (ii) their preference for learning and training; (iii) the key issues of environmental change and management they face that our research can inform. With such understanding the current and future research projects can better target local evidence-based policy for environmental management. To achieve this, surveys and interviews were conducted in two $\mathrm{CZ}$ research areas (the karst landscape in Guizhou and the red soils in Jiangxi), within which three of the projects of the China-UK CZ programme are based.

By doing this research (and that of the core science-based research) we now understand that KE (twoway knowledge sharing that informs project design) was and is not currently possible in the same manner as other NERC research activities. This is due to the following. First, the nature of the funding call (short timelines for submission) required the design of a research programme at the time of submission that had a high chance of success, and so activity was planned and structured with no time for stakeholder consultations prior to application to modify the research aims. Second, this KE research has revealed that the channels of communication with stakeholders is challenging for foreign research teams and would limit our likelihood of designing two-way KE at the proposal stage. These communication channels need to be understood and accessed via strong, well-connected Chinese research partners to facilitate two-way KE. Thus, the recommendations of this report are probably more tailored to ensuring effective knowledge transfer of the existing NERC- and NCSF-funded research outputs to stakeholders. In doing this, relationships will be built and communication channels established that allow future research building on this CZ Programme investment to effectively engage in KE in China.

Our research revealed that there was an urgent need to create more communication opportunities for the local stakeholders (farmers and officials from farm to county scale of governance) with scientists to improve their understanding about the landscapes they live and work in and to better engage in our $\mathrm{CZ}$ research. This was clearly expressed by the surveyed farmers, who would like to know more about what our scientists had been doing in their land and what had been found after many years research. The need for scientific communication and training was also supported by the survey results, which identified that these farmers were less educated and had limited understanding about the environment, and that insufficient training had been provided (Appendix Question Areas $1 \& 3$ ).

In terms of environmental topics, water source (quantity and quality) was of great relevance to farmers in both counties, while for the village/town leaders in Yujiang (red soil research area) soil- 
related issues (declining soil quality or soil loss) was a higher priority for their farmers (Table 1). In addition, farmers in both areas stated that buying fertiliser was the most expensive part of farming. Therefore, in order to best inform local farmers of good farming practice, sharing findings and understanding from our NERC NCSF research on the following topics is strongly recommended: i) how to improve water availability and quality; ii) how to reduce soil loss and enhance soil quality and; iii) how to avoid unnecessary use of fertiliser. It is also strongly recommended that local farmers and officials are taught more about how their activities impact on their local landscape.

Table 1 Important topics identified by local farmers and leaders in the karst and red soil landscapes.

\begin{tabular}{llll}
\hline $\begin{array}{l}\text { CZ research } \\
\text { area (county) }\end{array}$ & $\begin{array}{l}\text { Farming challenges } \\
\text { (by village/town leaders) }\end{array}$ & $\begin{array}{l}\text { Farming challenges } \\
\text { (by farmers) }\end{array}$ & $\begin{array}{l}\text { Most expensive part } \\
\text { of farming } \\
\text { (by farmers) }\end{array}$ \\
\cline { 2 - 4 } $\begin{array}{l}\text { Karst } \\
\text { (Puding) }\end{array}$ & $\begin{array}{l}\text { Earning an income (63-79\%) } \\
\text { Water-related issues (25-42\%) } \\
\text { Soil-related issues (25-33\%) }\end{array}$ & $\begin{array}{l}\text { Lack of labour (45\%) } \\
\text { Water source (28\%) }\end{array}$ & Fertiliser (78\%) \\
$\begin{array}{l}\text { Red Soil } \\
\text { (Yujiang) }\end{array}$ & $\begin{array}{l}\text { Soil-related issues (75\%) } \\
\text { Water-related issues (25-50\%) }\end{array}$ & Water source (34\%) & Fertiliser (88\%) \\
& Earning an income (25-38\%) & & \\
\hline
\end{tabular}

We explored how scientists can get involved better with local farmers and officials to share knowledge efficiently, and what the appropriate methods are to deliver KT and KE in the local context. This was done by 1) developing conceptual models of the science-policy-practice interfaces (Figure 1 in Section 2 Science-policy-practice interface) and 2) assessing the preference of farmers, residents and leaders for the types of KE practice that can best support their learning (Section $3 \mathrm{KE}$ preference).

The analysis of the science-policy-practice interface shows that it would be more effective to inform policy-making by connecting and interacting with the higher level of governance - national and provincial leaders, as they make political decisions. Thus, where possible, our scientists are recommended to build such active engagement. The leaders from relatively more local governance levels, particularly towns and villages, are the main points of contact who interact and communicate with local farmers in person. While they do not possess the right to make policies, it is important to inform them about the preferred and most effective ways to share knowledge with their farmers, so they can do this from a position of greater knowledge.

Apart from engagement with high level officials, there are two main links where researchers can deliver $\mathrm{KE}$ to local communities. First, the local governance leaders (particularly town to village level) need more science and technical support from the research community to deliver guidance for better farming and environmental protection; evidence of such support is currently lacking. Second, while training from researchers is sometimes provided to the local farmers, this often relies on the county level government to organise training courses and thus direct knowledge sharing between 
researchers and farmers, and local scale leaders (village and town) is very limited and needs to be improved.

On-site farm visits were the learning method favoured by the majority of farmers in both areas (almost all in Yujiang) (Table 2). This was followed by learning via training courses. In addition, both farmers and leaders were highly-supportive of the need for more demonstration farms to show examples of good farming practice. Research institutes, local government, larger, more established farms and agrotech officers provide a key role in promoting the use of demonstration farms for successful KE. Furthermore, to better balance limited time and training sources with farmers' opportunities to learn, it may be worth trying to engage more with agrotech officials (in both counties) and agricultural technicians in the local government-supported farming industries (at this stage we only know there are agricultural technicians working in the farming industries in Puding). These people have a better education and farming knowledge than most farmers, and their employment remit is to share knowledge and provide training to farmers. This can help improve the accuracy of knowledge and delivery of fair training opportunities - addressing concerns raised by the surveyed town/village leaders.

Table 2 Learning preferences of farmers and county leaders in Puding and Yujiang

\begin{tabular}{lll}
\hline $\begin{array}{l}\text { CZ research area } \\
\text { (county) }\end{array}$ & $\begin{array}{l}\text { Learning preference } \\
\text { (of farmers) }\end{array}$ & $\begin{array}{l}\text { Learning preference } \\
\text { (of county leaders) }\end{array}$ \\
\cline { 2 - 3 } Karst (Puding) & $\begin{array}{l}\text { Farm visiting }(60 \%) \\
\text { Training course }(30 \%)\end{array}$ & $\begin{array}{l}\text { Training course }(62 \%) \\
\text { Working with scientists }(46 \%)\end{array}$ \\
& $\begin{array}{l}\text { Written instruction }(8 \%) \\
\text { Poster/picture book (4\%) }\end{array}$ & No data \\
Red Soil (Yujiang) & $\begin{array}{l}\text { Farm visiting (96\%) } \\
\text { Training course (43\%) } \\
\text { Poster/picture book (35\%) }\end{array}$ & \\
& Written instruction $(28 \%)$ & \\
\hline
\end{tabular}

The detailed results (in the Appendix) in this report provide valuable information to underpin the design of future KE delivery and associated outputs, and to enable a more effective engagement with the appropriate stakeholder communities. This report also provides a clear framework for where KT activities are best tailored to share the science gained in the current China-UK CZO programme. Specific additional suggestions, from the KE understanding generated by our research, are provided for the existing pathway to impacts (PtI) of each CZ project (Table 3 in section 4). Note that as the five projects are approaching the end of current project life time for the UK teams, these additional suggestions would be suitable for the Chinese teams to implement in year 4 with the help of the UK teams or formally together should there be phase 2. In addition to the specific activities listed for each individual project, there may be economies of scale and improved KE delivery by working more closely 
across the five projects. This may be preferable in the final stages of each project, as gaining understanding of KE practice and doing science in a different country took considerable time. Some examples of potential efficiencies may involve:

a) Co-designing farm scale training activities across the 5-projects

b) Working together to identify provincial and national policymakers to whom we deliver briefing notes and delivering these outputs as a group effort, where applicable, to individual projects

c) Design and implementation of some 3-party meetings (e.g. across both projects in Puding involving scientists, officials and farmers) to help deliver CZ knowledge

d) Co-designing with the local agrotech officers or agricultural technicians from farming industries to help deliver KE to local farmers (e.g. across Puding and Yujiang)

It is also recommended that where KE activities are planned in the life of the current projects, or in year 4 of the Chinese components of your projects, that time is taken to evaluate the effectiveness of the implemented KT and KE activities. This can be measuring behavioural change in participants (before/after a training event) in a), to gauge how policymakers may use some of the science summaries produced in b) and to evaluate perceptions on the value of 3-party meetings suggested in c). These activities would be strengthened by involvement of social science colleagues for the analysis of behavioural change and would require ethics approval. These data would help provide some evidence of the impacts of your KT/KE activities on the targeted groups. 


\section{Rationales and aims of $\mathrm{KE}$ project in China-UK CZ programme}

For scientific research to reduce poverty and further sustainable development of the partnering countries (a requirement of Newton funding), it is important that the improved understanding of the critical zone from each $\mathrm{CZ}$ research project is communicated effectively to those who manage the environment and tend the land. To do this requires an appreciation of who the different users of this research are, what their baseline understanding of their environment is, and how they prefer to receive information and learn about their landscapes. To support the scientific research of the China-UK CZ programme funding was used to deliver a KE project, which focusses on the importance of, and the successful implementation of, KE activities in China.

KE activity, which is commonplace and successful in the UK, does not necessarily translate directly to implementation in China, and there may be cultural and political barriers, e.g. difficulties in accessing user groups as they are not involved in making the decisions and/or where some common dissemination tools such as decision support tools are not in regular use. Thus, there may have to be some reshaping of the proposed pathways to impact activities to accommodate the previously unknown challenges. This will be manageable but will be most successful if these 'hidden' challenges are understood and used to design activity that will work most easily.

A fundamental aim of this KE project was to research and analyse current KE activity in China and provide a baseline understanding of the different users of the outcomes of this research (Aim 1). Here, the science producers are UK and Chinese scientists, and the users are mainly government officials and residents who live in and manage the Chinese landscapes. This understanding (Aim 1) can then be used to advise the $\mathrm{CZ}$ projects what may be effective for their $\mathrm{KE}$ implementation (Aim 2). Thus, this $\mathrm{KE}$ project provides a mechanism to facilitate better understanding and 'broker' knowledge-sharing between these two groups to help ensure that the outputs of the China-UK CZ programme will deliver for the needs of users in the studied $\mathrm{CZ}$ areas.

We undertook this research by conducting two social surveys using questionnaires and interviews. The survey was initially carried out in Puding County, Guizhou (where the karst field sites are located) from 19 - 23 November 2016, and extended by a second fieldwork campaign to include Yujiang County, Jiangxi (for the red soil field site) on $7-10$ March 2018. This second survey was included for larger survey coverage and better KE understanding from multiple CZ sites. This was all that was possible in the time available. The detailed survey results are in Appendix, with relevant sections to each discussion point detailed in the body of the report. 


\section{Science-policy-practice interface}

In both counties, an understanding of how groups of scientists, government officials and practitioners interact and collaborate with each other was generated from the semi-structured individual and group interviews with local government leaders. Where this sectional analysis allows it, how KE can be promoted will be identified, discussed and subsequently encouraged.

\subsection{Similarities}

In the process of knowledge sharing, a hierarchy between different levels of governance has been observed and this is similar between the two counties.

a) The national/province/city officials make high-level policies, initiatives and decisions for the environment and farming practice. For example, an initiative promoted by the national government and involving various academia to promote the science and technology development has been established in both Guizhou (with karst landscapes) and Jiangxi (with red soils) Provinces. The promotion of this initiative in each province had to be approved by the provincial government (normally the Science \& Technology Association and Science \& Technology Department). This initiative has helped, e.g. the development of rice-fishing cultivation models in Yingtan City, Jiangxi (which oversees Yujiang County under its administration) to protect the local ecosystem ${ }^{1}$. At the higher-levels (the national/province/city), governments also provide funding for the proposed and permitted training events.

b) County leaders perform a similar role in awarding funding, although instead of making policies, they make local regulations. Town and village leaders transfer the information of county-level policies and regulations down to the next level, to communities and ultimately to farmers. Therefore, village and town leaders have more interaction with farmers and thus are well-placed to provide advice on farming activities. However, most training for farmers is proposed or initiated by county leaders and passed to and organised by town/village leaders for farmers.

c) An agrotech officer to provide advice and help to local farmers is a common governmental position existing in both counties (although whether this role operates at the town or village level varies (Figure 1). This government role may be important to help promote more efficient $\mathrm{KE}$ for the $\mathrm{CZ}$ programme.

d) Training is designed for and delivered to town/village officials, development as part of their job role to better advise on farming practice. Here scientists provide training courses to these local-level officials. In addition, scientists also train the local farmers, but this is largely organised and scheduled by county or higher levels of government. 
e) Large farming industries (observed and interviewed in Puding) or farming households in both counties often receive direct support from the local government, before individual farmers did. This is to increase the training efficiency and outcomes, as there is limited training funding. However, it inevitably decreases the learning opportunities for the small farming households. This may partly explain the survey response that farmers suggested limited interaction with the local government and scientists for learning and both groups played a limited role in KE with farmers, while the local government reported to have provided training,

Instead, farmers obtain their farming and environmental knowledge from other groups including personal experience, family, friends, fellow farmers, and seed sellers. For both sets of farmers surveyed, knowledge passed by generations is one of the most significant sources for their learning, and they largely valued this family knowledge.

\subsection{Differences}

a) In Puding (with karst landscapes), a new KE method using social media (WeChat) is increasingly used for direct communication between researchers/experts and town and village leaders. Such a connection is often established by leaders attending training courses and enables continued advice after a training course ends. This enables the leaders to share and communicate the farming issues better with the experts and leaders from other villages/towns attending the same training courses. However, the use of social media was not mentioned in Yujiang (with red soils) during the survey. Instead, the Yujiang leaders receive support on farming and village development from a few appointed universities and institutes (including Jiangxi Academy of Agricultural Sciences, Jiangxi Agricultural University). This may indicate the Yujiang government has a strong and stable collaboration relationship with the local research community that could be strengthened further (e.g. by the support from the Academician Workstation in Yingtan). Although appointed institutes like this are also present in Puding, it was not mentioned by any level of the government during our interview which may be a sign of weak interaction. However, researcher secondment was observed in Puding county, e.g. Dr Tao Peng from P-KERS working as the deputy county mayor of Puding. This is helpful in facilitating the direct communication between the local research community and the government.

b) Agrotech officers are part of the village governance in Puding but operated at town level in Yujiang. This may suggest that in Puding farming advice from agrotech officiers for farmers is more accessible. In Yujiang, being set up at a higher level, the agrotech officers may have more direct and sufficient personal learning opportunities to be better at their job. However, due to the greater responsibility for more villages, they are less accessible for many of the farmers to interact and communicate with. 
c) Due to the ongoing implementation in Puding of the national land management policy which transfers the right to use land from individual farmers to larger farming cooperatives, government-supported farming industries are emerging, which hire individual households to work for them. As a result, these industries, particularly their agricultural technicians, become new and potentially key players in knowledge sharing with local farmers, as technicians teach farmers about new farming techniques. Moreover, direct communication occurs between these farming industries and scientists. Researchers are invited to provide in-person farming guidance to the agricultural technicians periodically. This land transfer policy was not mentioned during our fieldwork in Yujiang by neither farmers and officials (which may be due to the different proceeding of the implementation), which may lead to different land management situation between the two counties.

d) In Puding, seed sellers were mentioned by the farmers as important sources of information and farming guidance, but were not mentioned in Yujiang. For example, sellers provided suggestions on how much fertiliser should be applied for a certain area of farmland. More information is required from future surveys to confirm where the sellers learn their fertiliser knowledge and how impartial/scientific their advice is. However due to the frequent interaction between seed sellers and farmers (and maybe farming industries too), it is recommended that farmer-seed seller interactions are encouraged to promote KE, and that future research projects seek to partner with seed sellers to deliver KE.

e) Compared to Puding, in Yujiang a larger percentage of farmers learn farming and soil knowledge from the government and local research communities. This may suggest better support across the science-policy-practice interface for Yujiang farmers from these two groups. Specifically, some farmers reported learning from Yigntan Station, where the Red Soil CZ project is based, when they collaborated with the scientists by helping with their fieldwork or letting out their farmland for research.

The similarities and differences between the two counties are summarised in Figure 1. 
a. Yujiang County

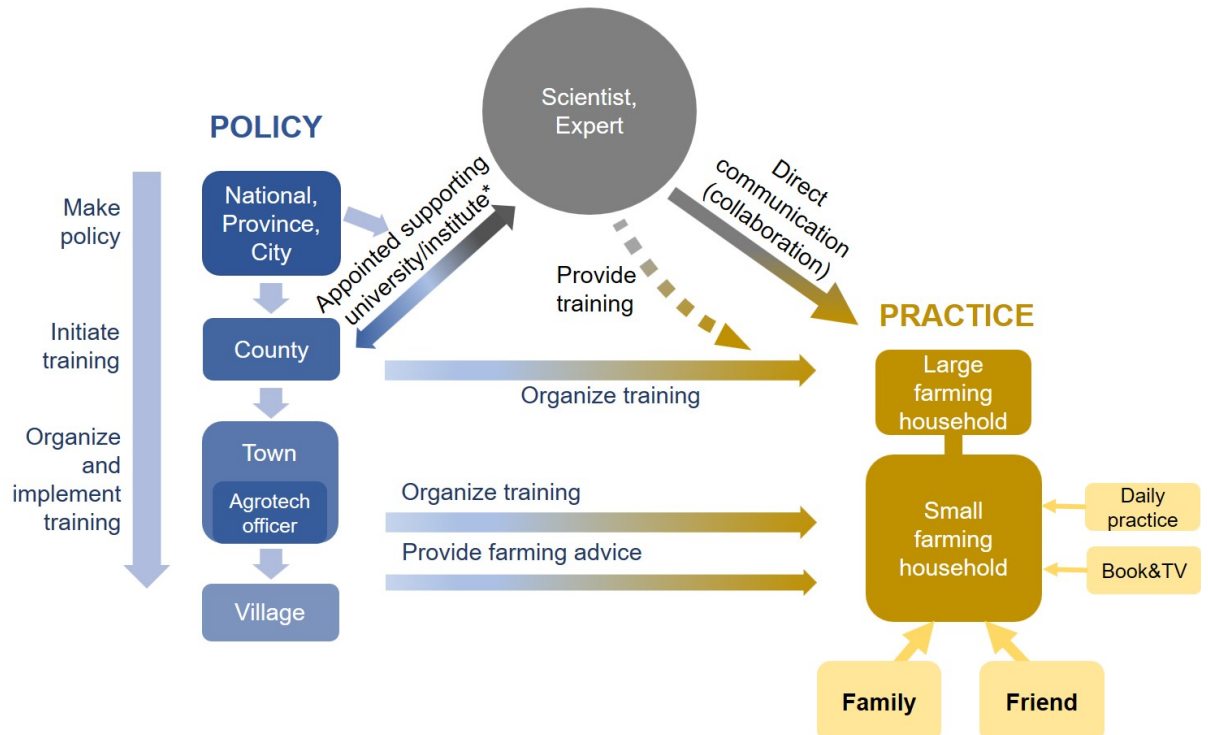

b. Puding County $\quad$ SCIENCE

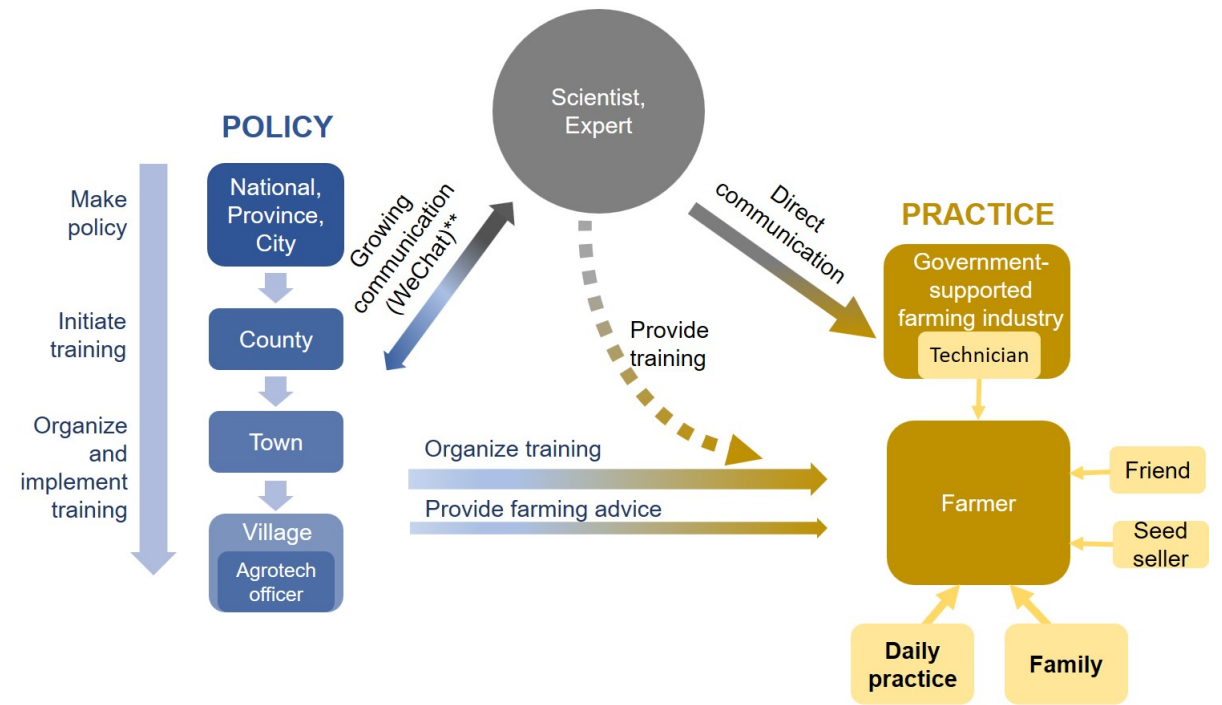

*Including Jiangxi Academy of Agricultural Sciences, Jiangxi Agricultural University, Jiangxi Academy of Sciences, Yingtan Farmland Ecosystem National Field Observation and Research Station (hereafter short for Yingtan Station)

${ }^{* *}$ Only those attending training courses

Figure 1 Science-policy-practice interface during knowledge sharing in a) Yujiang County and b) Puding County. The colour codes are: blue for government, grey for research community and yellow for the practitioners (here mainly farmers and farming industries). The solid lines suggest a direct interaction while the dashed one means a mediated in-direct interaction. The size of arrows signifies the frequency of the represented activities or interaction. The size of PRACTICErelated boxes shows the relevant importance. 


\section{KE preference}

\subsection{Learning preference among the current methods}

Farmers in both counties strongly-favoured farm visits by scientists and farming experts (Figure 2), particularly in Yujiang which showed an overwhelming interest in this form of learning opportunity (96\%). However, this was not used as frequently by both local governments. Farm visiting was followed by attending training courses (Puding: 30\%; Yujiang: 43\%). Written materials (posters, picture books and instructions) were least preferred by farmers, but Yujiang farmers had a greater interest in written materials than in Puding.

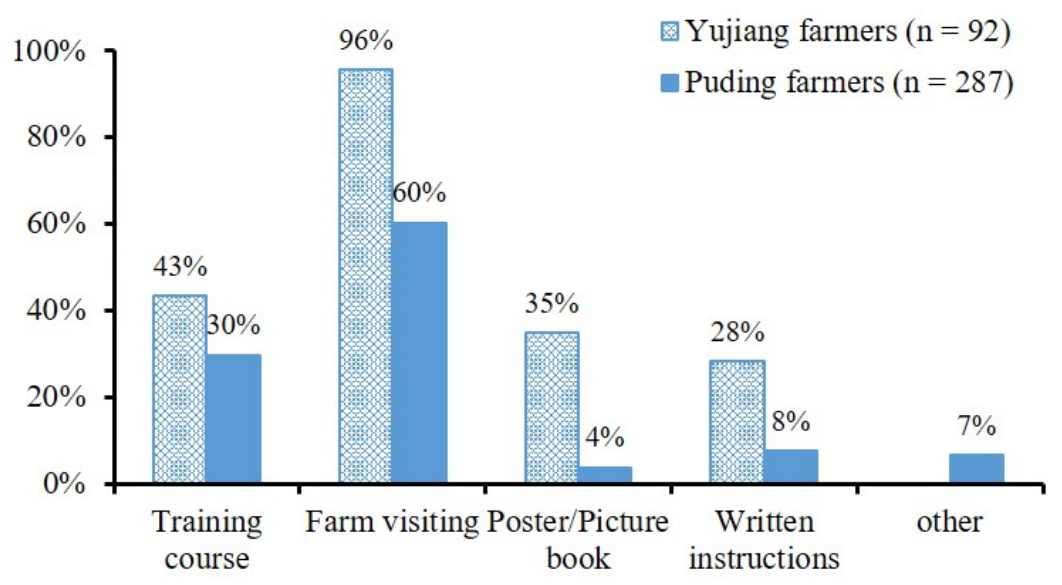

Figure 2 Methods preferred by farmers to learn knowledge (respondents could choose more than one answer).

\subsection{Demonstration farm}

The survey indicated that having demonstration farms was highly recommended in both counties by farmers (and leaders too). This is a method where farmers can see the trials and learn by practice. The method could be more convincing and attractive for farmers when presenting successful results than only attending training and reading written materials, given that farmers are likely to relate to the idea that 'Practice is the sole criterion for testing truth' (by Chair Mao).

Some of the current demonstration farms are co-supported by local government, research institutes and industries (e.g. rice-turtle paddy fields in Jiangxi Province), and some successful examples are in other provinces, in which case the government leaders and agrotech officers would visit and learn via travelling. The surveyed leaders in both counties indicated "there are limited demonstration farms" and "more are needed". A Yujiang county leader suggested "the demonstration farms can be guided and supported by the government, tried by a few large and well-developed farming households, and promoted by the agrotech officers". This represents an opportunity where scientists can co-design the trial farms and provide science and technical support. 
However, in the Nanjing CZO meeting (April 2018), different opinions were reported from the attending scientists on the value of demonstration farms. Thus, it is important to explore more about the cause of the discrepancies between the researchers and stakeholders in terms of demonstration farms. For example, understanding how the demonstration farms are currently used by the government and research institutes and what the farmers' perspective is on receiving the benefits from the farms may be worth exploring.

\subsection{Farmer representatives}

With the national policy of taking targeted measures of poverty alleviation ${ }^{2}$, more efforts have been made by these two local governments to provide science knowledge and training to help farmers. For example, in 2017 about 150 farmers received farming training from Huangtong Town in Puding County, which is an improvement compared to the number of farmers received training before the new policy was implemented. However, the training and human resources are still limited in the two counties (Appendix Question Area 3.3), sometimes leading to training events being organised for only a small number of farmers. If these learning opportunities are distributed to a few farmers, who are normally the large and developing farming households, or more experienced farmers with a better farming knowledge (hereafter referred as 'farmer representative' in the text), they then may help share the knowledge with other farmers in their villages. When surveyed in Puding, mixed opinions from among farmers and leaders were shown regarding this method (Appendix Question Area 4).

Some leaders and farmers felt that having a farmer representative would make it easier to organise training events in terms of arranging training location, timing and people to attend. It would also allow the farmers to have a more convenient access to these representatives as they know each other in the same village. Farmers would be able to learn successful practices by talking with others and copying.

However, concerns were also expressed by farmers and leaders. Firstly, farmers argued the equal opportunities of being chosen as the representatives who can learn the knowledge directly from the professionals - who makes the choice? Secondly it was difficult to ensure the accuracy when sharing knowledge between representatives and other farmers - how correct is the passed knowledge? Thirdly, some farmers worried whether representatives would share all new knowledge or retain some to provide a competitive edge - is it all of it? Concerns that farmers prioritised family and farming activity over being a farming representative were also mentioned by farmers and leaders, which may be potentially and partially resolved by an appropriate incentive method. Thus this approach may not have the uptake the leaders desired and so knowledge dissemination would be limited.

To help effectively ease some of the concerns, better support and financing of the agricultural technicians in the farming industries emerging in Puding may be a method worth promoting. These 
technicians are skilled in the relevant farming techniques to ensure the knowledge is correctly shared with farmers, and it is their primary job so they can dedicate time to it. They do not have direct competition with local farmers, and if paid (e.g. by the government, or relevant research project funds), they may help train farmers locally outside their normal working hours in the farm industries.

\section{Suggestions for KE delivery in Yujiang \& Puding}

Our KE research allows us to consider the existing pathway to impacts (PtI) of each CZ project and how effective these may be, and make suggestions of amendments then may make these more effective (Table 3). In addition to the $\mathrm{KE}$ recommendations for the five $\mathrm{CZ}$ projects now possible from this postsurvey position of understanding (Table 3), we can suggest better future KE design and delivery for Yujiang and Puding. These will directly benefit three of the five $\mathrm{CZ}$ projects, but some recommendations can also be useful for other projects. In recent years there has been an increasing awareness of the difference between $\mathrm{KE}$ and $\mathrm{KT}$, where $\mathrm{KE}$ is a mutual sharing dynamic between researchers and users while KT is one-way delivery from researchers. The UK researchers designed the $\mathrm{CZ}$ projects with $\mathrm{KE}$ approaches in mind. However we now understand the stakeholder interaction in China is different from the UK interaction and so there have to be some adjustments. Thus the approach we suggest here is to ensure KT occurs, and in doing so the relationships can be established to support $\mathrm{KE}$ in the future. 
Table 3 KE suggestions for each of the CZ projects about their current pathway to impact (PtI) activities

\begin{tabular}{|c|c|}
\hline Project & Originally Proposed Pathways to PtI Activities \& Revised Recommendations \\
\hline \begin{tabular}{|l|} 
SPECTRA \\
(Puding County, \\
Guizhou Province)
\end{tabular} & $\begin{array}{l}\text { Original Proposals } \\
\text { 1. Engagement of the user community in China: e.g. forum events and field visits with the regional stakeholder community, regular } \\
\text { meetings between the Chinese/UK scientists and the regional stakeholder community } \\
\text { 2. Webinars between UK and Chinese teams, and Chinese team and local land managers (adopting the Science \& Technology } \\
\text { Backyard approach) } \\
\text { 3. End of the project: an event with from individual farms to national policies; providing a leaflet in non-scientific language } \\
\text { 4. Engage with regional and national policymakers via policy briefing notes } \\
\text { 5. Interaction with Chinese/UK school children } \\
\text { 6. Develop a public project web, update in social media } \\
\text { 7. Engagement of the CZ network } \\
\text { Comment \& Recommendations } \\
\text { i. Where the access is available, it is highly recommended to engage with the high-level government (i.e. city or province), so it is } \\
\text { great that the SPECTRA project can actively share knowledge with regional, provincial and national policymakers. The challenge } \\
\text { will be to find ways of getting connections at this level so that your science can be shared. } \\
\text { ii. Knowledge of best management practices for fertiliser applications coupled with understanding of water sources were identified as } \\
\text { being of high importance to the local communities. Communicating simple best management practice advice based on research } \\
\text { findings should be encouraged. Additionally, it was strongly recommended by both officials and researchers at our meeting with } \\
\text { Puding county level government to have 'three-party' meetings that involve farmers, government and scientists. This could be } \\
\text { incorporated in the regular engagement if possible or otherwise in the event at the end of the project. } \\
\text { iii. It is recommended to deploy different engagement activities according to the needs of different stakeholder groups. Field visits are } \\
\text { favoured by most of the local farmers, whilst forum events (which may be similar to training courses) are likely to be popular with } \\
\text { county leaders. } \\
\text { iv. Written materials are welcomed by only a small number of farmers but more favoured by the government officials, thus a } \\
\text { recommendation would be to replace the leaflet for farmers with farm visiting or training courses and/or create a leaflet pitched } \\
\text { towards government officials rather than farmers. }\end{array}$ \\
\hline
\end{tabular}




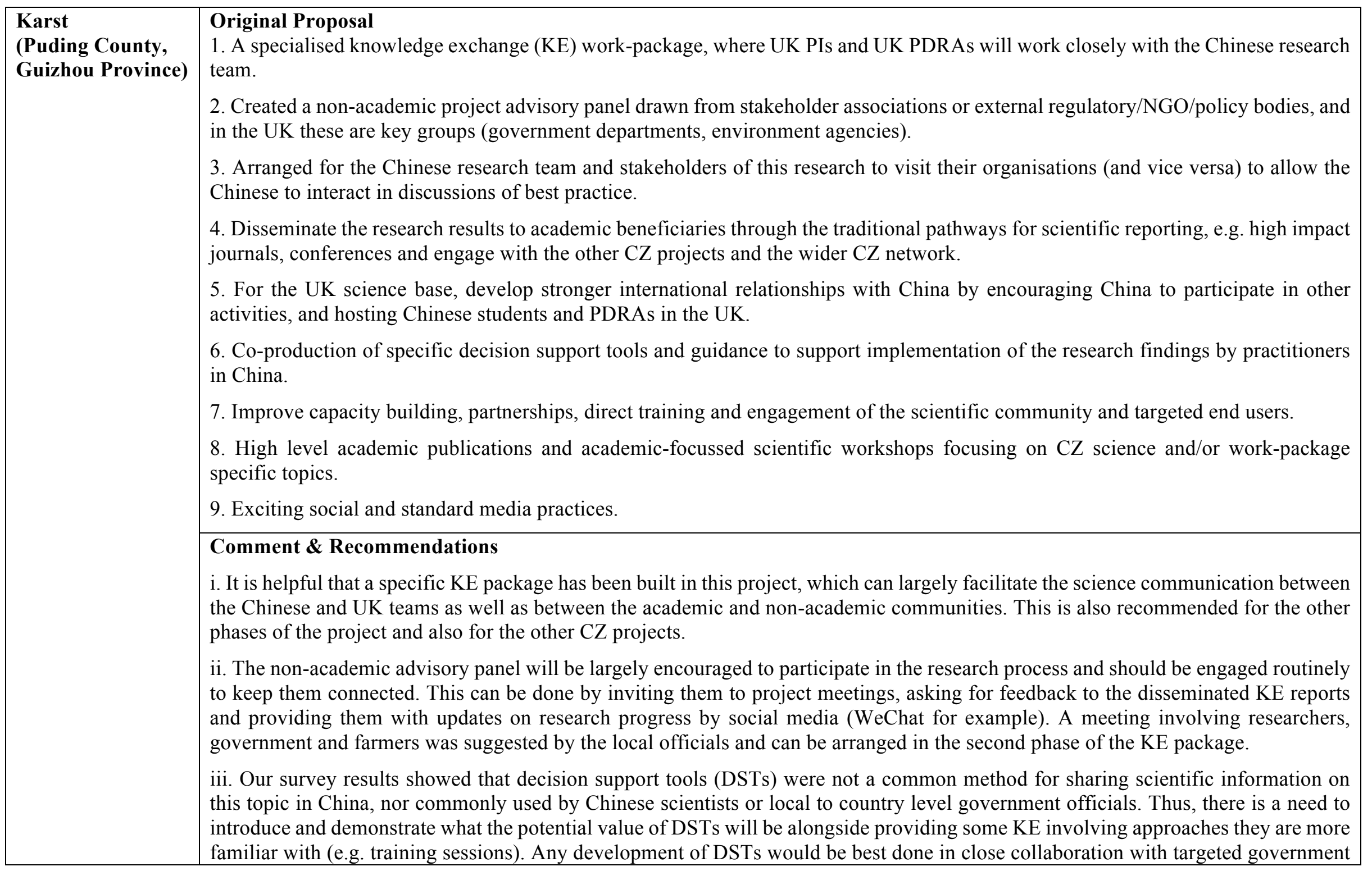




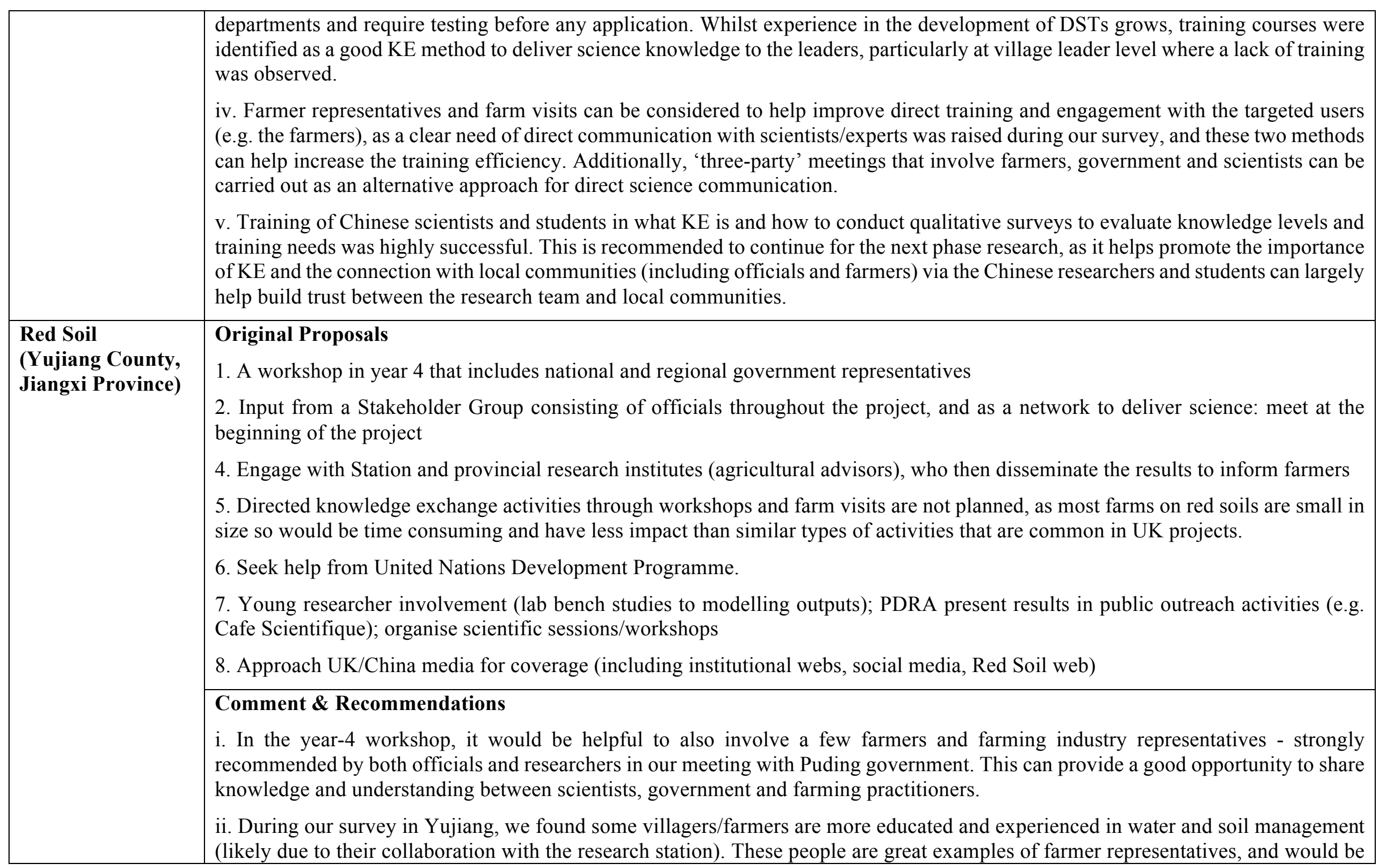




\begin{tabular}{|c|c|}
\hline & $\begin{array}{l}\text { very helpful in disseminating the results to inform farmers with research institutes. Incentives will be needed to get them involved } \\
\text { (e.g. payment). } \\
\text { iii. While workshops and farm visits can take time, in the Yujiang survey } 96 \% \text { of the surveyed farmers strongly-favoured farm visits } \\
\text { and in-person communication. Thus, we would still suggest providing some farm visits as a training method for Yujiang farmers. This } \\
\text { can be arranged with the collaboration with the agricultural advisors (mentioned in the initial proposal) building on their relevant } \\
\text { experience in disseminating knowledge to farmers. }\end{array}$ \\
\hline \multirow[t]{2}{*}{$\begin{array}{l}\text { Peri-Urban } \\
\text { (Ningbo City, } \\
\text { Zhejiang } \\
\text { Province) }\end{array}$} & $\begin{array}{l}\text { Original Proposals: } \\
\text { 1. Engagement by all impact partners in the project implementation planning via site visiting } \\
\text { 2. Joint design and delivery of plot studies (as a demonstrator) with farming practitioners; annual visit day for farm practitioners } \\
\text { (20/year) } \\
\text { 3. A KE workshop with environmental agency staff and industry leaders: fact sheets, oral presentation, video presentations, working } \\
\text { sessions for scientists } \\
\text { 4. NERC Impact Accelerator support for the UK workshop, and } 15 \text { industry participants in the UK workshop } \\
\text { 5. Membership of } 10 \text { companies and agencies in the industry club; a } 5 \text {-year development plan for the industry club in partnership with } \\
\text { the CZO; } 3 \text { industry club members contributing time to deliver content in the final year project summer school } \\
\text { 6. Final conference with } 30 \% \text { participation from non-academic leaders in the impact sessions }\end{array}$ \\
\hline & $\begin{array}{l}\text { Comment \& Recommendations } \\
\text { i. The engagement of impact partners in the project planning should be effective because it could help shape the research design from } \\
\text { the early stage. } \\
\text { ii. The plot studies with farming practitioners should be encouraged, as this is the training method suggested by many officials and } \\
\text { farmers in our survey (although this question was only asked at karst field sites). Where possible, it would be also effective to hire a } \\
\text { few experienced and educated farmers as farmer representatives, and this may help increase the learning efficiency over and above } \\
\text { that from the annual visit day proposed in the original plan. } \\
\text { iii. The long-term development plan with the industry club should be effective, as this will help gain the trust and maintain the } \\
\text { relationship between scientists and stakeholders. } \\
\text { iv. The majority of the KE activities are arranged at the beginning and end of the project. As the project is nearing completion, } \\
\text { focussing on the project end KE activities and encouraging sustainability of the training, via training of local people who can re-run } \\
\text { events in future would be a good approach. In future projects, it would be also beneficial to engage with the relevant stakeholders }\end{array}$ \\
\hline
\end{tabular}




\begin{tabular}{|c|c|}
\hline & $\begin{array}{l}\text { during the project lifetime to keep them informed and interested. This can be combined with the KE workshop with the environmental } \\
\text { agency and industry club by making this as a routine event (e.g. biannual or annual). } \\
\text { v. In addition to the environmental agency, engagement with the high-level officials who have more influence in policy decision } \\
\text { making could be beneficial. }\end{array}$ \\
\hline $\begin{array}{l}\text { Loess Plateau } \\
\text { (Yangling, } \\
\text { Changwu, Fuxian, } \\
\text { An'sai and } \\
\text { Shenmu County, } \\
\text { Shaanxi Province) }\end{array}$ & 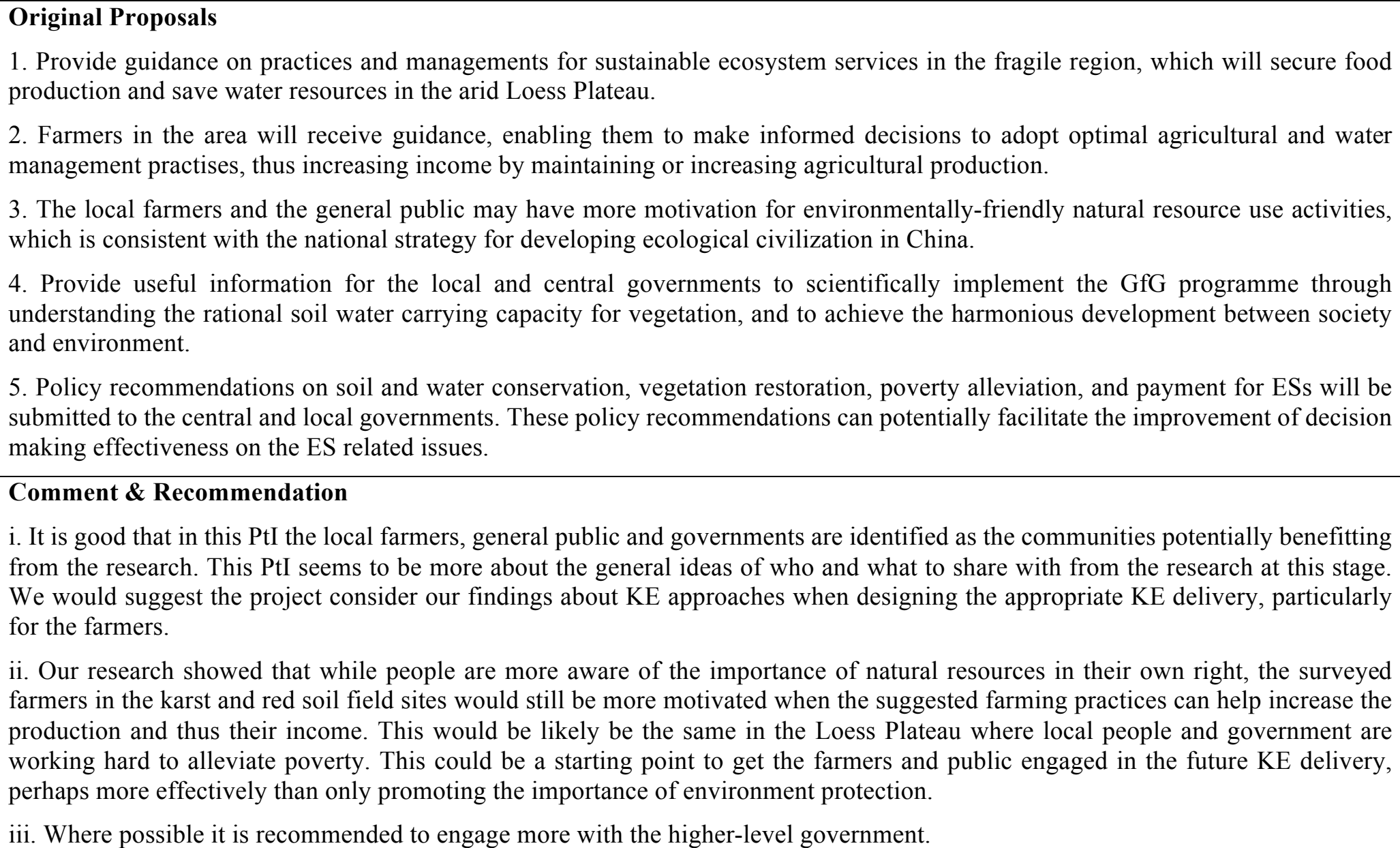 \\
\hline
\end{tabular}


Early engagement with the local communities, particularly farmers, farming industries and government, is highly recommended. The early communication of research purpose could help garner potential support, such as government funding. In both Yujiang and Puding, specific funds for promoting farming techniques in villages are available in several county departments and there was positive feedback during the county leader interviews to encourage the scientists to get in touch and apply for such funds. Although the UK funding for $\mathrm{CZ}$ projects is approaching its end, the local funds could still be an important resource to help deliver $\mathrm{KE}$ in the latter research stage (there will be on-going engagement with the Chinese co-Is in their year 4 of funding), which is when most understanding is consolidated. Thus this pathway may not be too late. For example, the PtIs in many projects proposed to interact with farmers for sharing their research results. The engagement with those county departments may not only provide additional funds for organising such KE events, but more importantly, could help establish a new connection with the local government that can be developed into a long-term relationship and increase the research impacts.

Furthermore, for the purpose of informing decision-making, we would encourage all researchers to interact with the higher-level local government. While the regional and national government may be difficult to reach as establishing the route into governmental networks requires the right connections and takes time, the county level could be a good start. The county officials in both Yujiang and Puding appeared receptive during interview for supporting environmental research, and especially in Puding a relationship between the $\mathrm{CZ}$ researchers and the county government has been successfully established via one scientist of the Chinese research team being on secondment to county government, and via project meeting and KE activities. The communication and collaboration with the higher-level government also benefits the smooth KE delivery in villages and towns considering the hierarchical governance structure.

In terms of the recommended $\mathrm{KT} / \mathrm{KE}$ methods, training through farm visits is of great interest to the farmers in both counties. Demonstration farms were favoured by both the farmers and leaders as more tangible example for introducing new farming practices. In Puding, while more training has been provided in recent years, there is still high demand from the farmers and leaders to learn new farming knowledge. Thus, it may be helpful to increase the training efficiency by having farmer representatives. To avoid the concerns raised by the village leaders and farmers about ensuring knowledge channelled this way is distributed evenly and fairly, maybe appointing more agrotech officers in the villages or the agricultural technicians in the farming industries can be financed to perform the role of representative (e.g. perhaps via the county research fund). In Yujiang, the survey did not involve questions about farmer representatives (due to the reasons stated earlier). However, the farmers/villagers working with Yingtan Station are more educated and know more about the research in Yujiang than other farmers, and thus can be good candidates for such a role if also favoured in this area. 
In addition, all PtIs suggested increasing research impact via social media. This seems like a good idea as some of these approaches to communication already exist in China. Here we would suggest incorporating the Chinese social media, WeChat, in this process as it is commonly used in China. WeChat was used by some of those interviewed; this included county to village level leaders for KE, e.g. continuous learning from trainers and with other leaders in WeChat group after attending training courses. However, it should be noted that despite the large use of this mobile application, it may have limited reach among villagers and farmers in Puding and Yujiang, most of whom are $>40$ years old and received limited education. Therefore, WeChat may be a KE method more applicable for residents in town to city levels and in peri-urban to urban areas.

Finally, workshops and project meetings are helpful in communicating and disseminating the research results from the CZ. During the surveys in both counties, farmers commented often that they would like to know more about the research being undertaken on their lands, and they reported that this information was currently lacking for them. Moreover, the city and county leaders in the karst sites strongly support the idea of having project meeting with researchers, government and local farmers. This could be an exciting science-policy-practice interface facilitating the communication of $\mathrm{CZ}$ knowledge. Many projects suggested to have workshops only at the end of project; however, organising such events more routinely, e.g. annually, would seem to be more effective in maintaining a stable relationship with the relevant stakeholders, keeping them engaged and ensuring the research outputs are disseminated as widely as possible

\section{Summary}

This report provides understanding about the science communication dynamics in two Chinese counties hosting three of our five $\mathrm{CZ}$ research projects. The results have focused on the farming issues that our $\mathrm{CZ}$ science results can help with, the science-policy-practice interface during KE process, and the opinions of the local farmers and government leaders on various KE approaches. From this understanding, we have been able to provide some suggestions for how to delivery KE more efficiently in China rural areas across our five CZ projects and for each of the individuals. However, important is that this understanding and knowledge of how to ensure research outputs can be of value to the stakeholders can be incorporated into subsequent activity, for example if there is a phase 2 of this research. Phase 2 would be a joint activity, but independent of this funding there is valuable information in this report to help the Chinese team design KE activities suitable for their research areas, as scientific understanding is condensed in year 4. This will support best the $\mathrm{CZ}$ research but also establish communication channels that would allow more stakeholder input at the beginning and throughout future projects whose function is to improve the quality of life for stakeholders. 


\section{Appendix}

This appendix summarizes the survey results, structured to identify the purpose of the survey questions.

\section{Question Area 1: Demographics and understanding about environment}

The local landscapes in Yujiang and Puding were maintained mainly by the farmers older than 40 years old (Figure 3). Most of them had limited education: in Yujiang, $47 \%$ of the surveyed farmers were only educated to primary school level and $36 \%$ to middle school level (Figure 4, no data available for Puding due to the primary design of questions). It is important to recognise level of education when designing $\mathrm{KE}$ approaches to be more accessible.

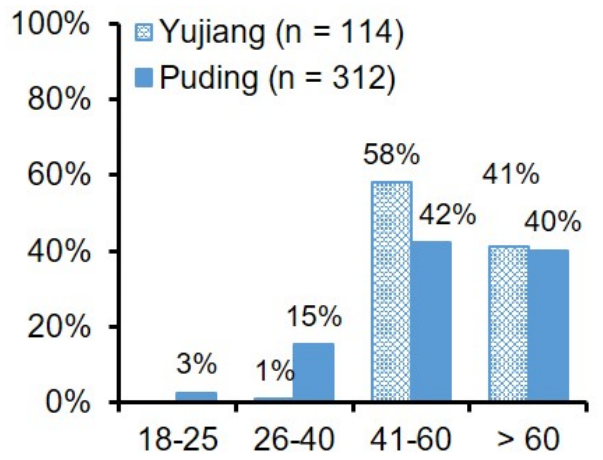

Figure 3 The age distribution in Yujiang and Puding counties.

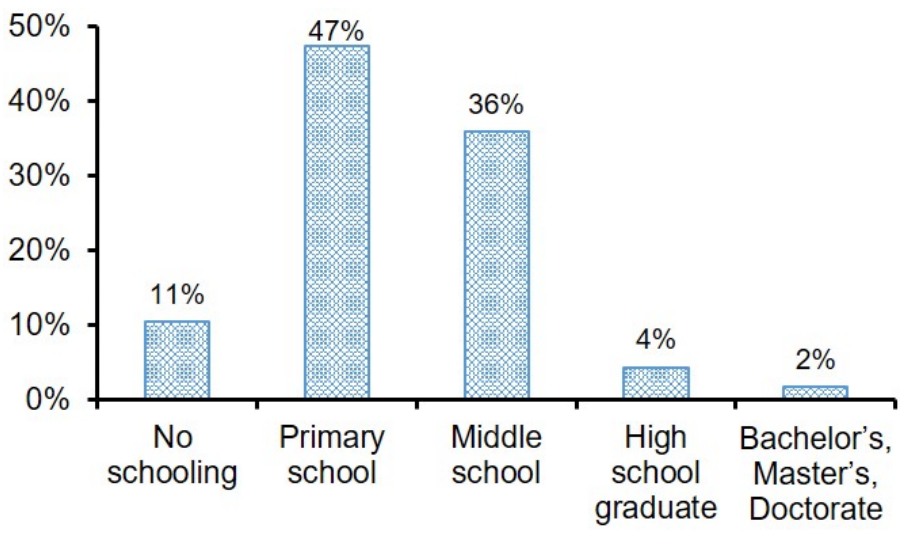

Figure 4 The education level of the surveyed farmers in Yujiang county $(\mathrm{n}=114)$.
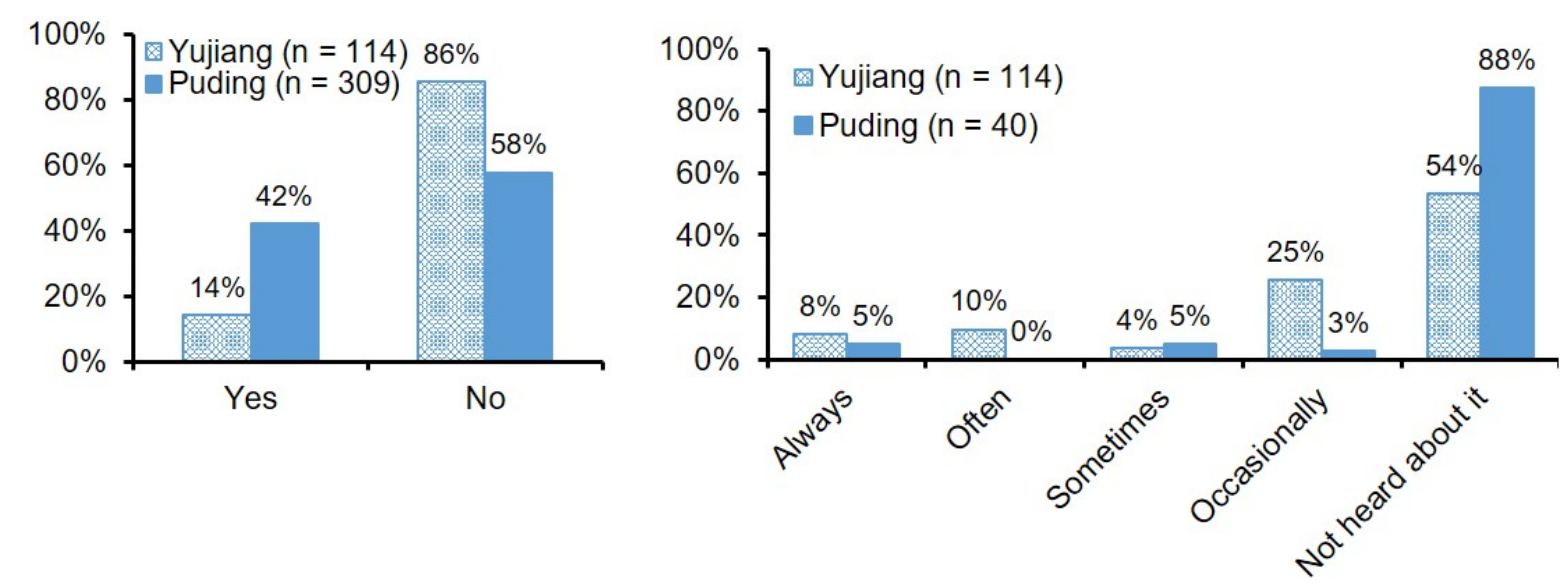

Figure 5 Do the farmers think any of the farm activities (e.g. tilling, fertiliser or chemical use) they do on their land affect

Figure 6 How often have the farmers of Yujiang or Puding heard about the term 'red soil' or 'karst'? other farm land nearby? 
More than half of the farmers in each county ( $86 \%$ in Yujiang, 58\% in Puding) considered there was no impact of their farming activities (e.g. tilling, fertiliser use) to other farm land nearby (Figure 5). This may indicate that the farmers from both counties had little knowledge about environment and how their farming practice might have negative impacts on the environment.

In addition, farmers were asked how often they have heard about the term 'red soil' (for farmers in Yujiang) or 'karst' (farmers in Puding), and most of them reported little or no knowledge of these terms (Figure 6). However, during the interview, the researchers found these farmers formed their own knowledge about the soils from daily experience, e.g. the Yujiang farmers had dialects to describe the red-brown soil, and Puding farmers realised their soil was poor in nutrients and difficult to grow plants. These findings suggest the farmers may generate their environmental understanding largely from their farming practice and experience (which is supported by the survey results shown in Figure 11), but not systematically from education. As a result, the provision of training is needed for both places and appropriate KT methods can be developed, and where possible combining this with the farmers' practice experience they have generated to develop two-way KE.

\section{Question Area 2: Biggest challenges by farmers \& how to be more productive}

Farmers from the two counties were asked about the biggest challenges in their farming activities. Water resource (including water quantity and quality) was reported as one of the major challenges in both locations (Figure 7). In Puding, the lack of labour was the greatest concern to nearly half of the farmers, while it was much less of an issue in Yujiang (only raised by $12 \%$ of farmers). Other issues including technology and fertilisers were also identified as challenges to some of the farmers (only $9-16 \%$ ) in both counties.

In addition to the biggest challenges (water quantity and quality), farmers also reported the most expensive part of their farming activity. In both counties, fertiliser cost was the greatest expense (suggested by $88 \%$ of 114 Yujiang and $78 \%$ of 308 Puding farmers), followed by tools $(8-12 \%)$ and water for irrigation $(1-8 \%)$, respectively (Figure 8). In the town and village leader surveys, earning an income was suggested to be the greatest pressure for farmers in Puding, and soil-related issues in Yujiang (Table 1). Excessive use of fertiliser can lead to environmental pollution and if this could be communicated and the correct use assessed then our $\mathrm{CZ}$ research could largely help reduce financial pressure on the local farmers and offer greater environmental protection.

In terms of the types of support and interventions that could help improve the productivity and/or income generating capacity of their farms, slightly different responses were found between the two counties. In Yujiang, more financial support was selected by $>80 \%$ farmers, followed by more land 
(76\%) and training (67\%). Only $<40 \%$ of the farmers chose more labour to help them. However, in Puding, these four options were more evenly selected by the local farmers (ranging from $33-42 \%$ ).



Figure 7 What is the biggest challenge the farmers face in farming their land? (choose one only)



Figure 8 What is the most expensive part of farming activities of the local farmers? (choose one only)



Figure 9 What would help your farm be more productive/generate more income for your family? (circle all that apply) 


\section{Question Area 3: Current knowledge exchange practice}

\section{Self-learning process within practice communities}

Farmers from both regions greatly relied on their families to learn farming knowledge - 74\% of Yujiang farmers reported learning from families and more so in Puding, with $98 \%$ of farmers learning from family (

Figure 10). Almost no farmers described learning farming methods from university or college (1\% in Yujiang and none in Puding). Differences were observed between the locations about where the farmers learned from. Learning from friends and fellow farmers was valued more by the farmers in Yujiang (68\%) than Puding (31\%). In addition, a larger percentage of farmers in Yujiang learned farming from local government (23\%, although still small) than those in Puding (10\%).

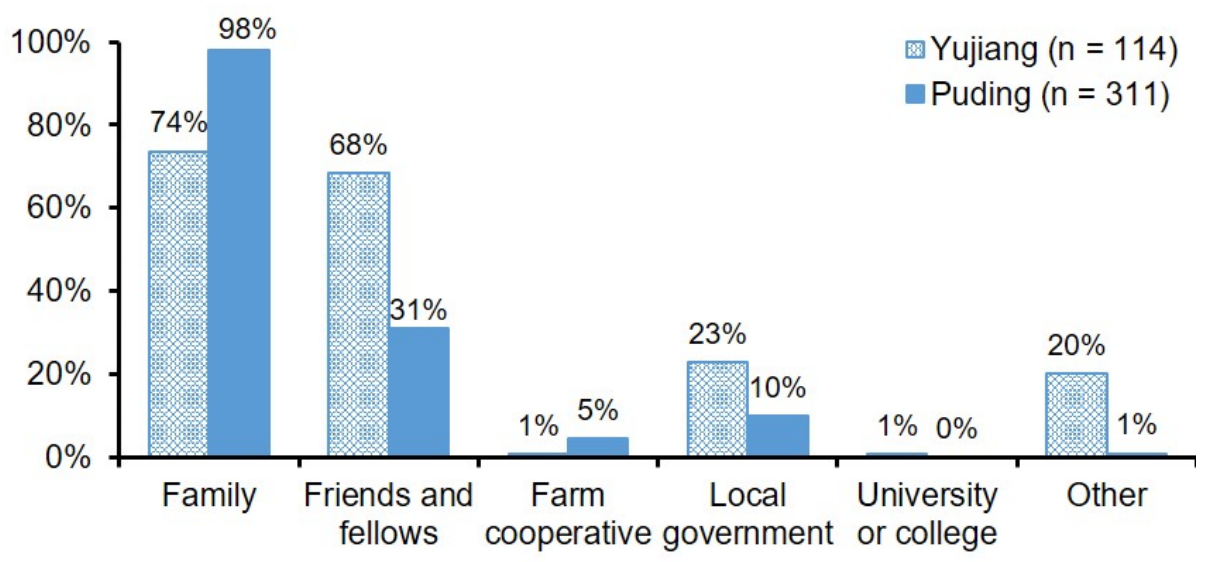

Figure 10 Where did farmers currently learn about farming methods? (respondents could choose more than one answer)
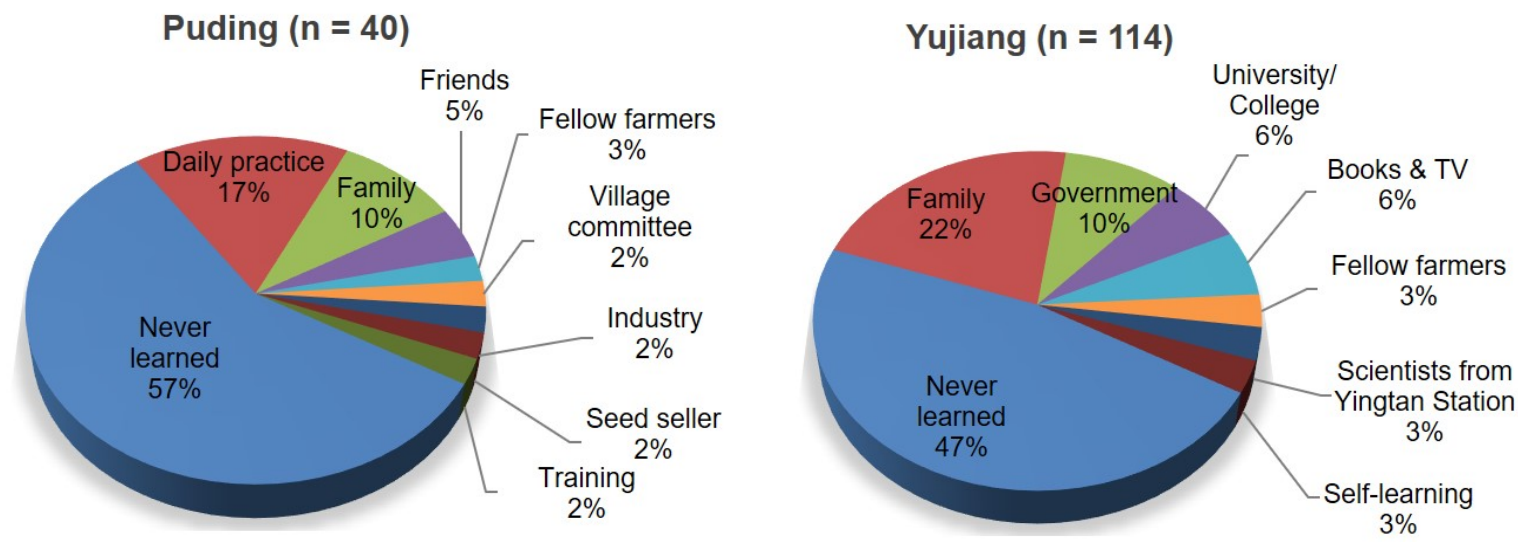

Figure 11 Where did the farmers in Puding (left) and Yujiang (right) learn about soil erosion?

We asked about soil erosion as an example to understand where the farmers learned about environmental knowledge. First, around half of the farmers indicated they never learned about soil 
erosion (Figure 11). Second, family again played an important role in their environmental learning: it was the second largest knowledge source in Puding and the largest in Yujiang. Third, while learning still occurred locally, farmers took advice from wider sources, including farming industries, seed sellers, books and TV. The interview provided more insight about these sources. For example, the Puding farmers learned from the seed sellers about the use of fertiliser, to avoid unnecessary overuse and to protect soil quality. Technicians from the emerging farming industries also provided advice about farming practice to the local farmers, who were employed by the industry. In addition, while scientists were absent from the learning practice in Puding, 3\% of the surveyed Yujiang farmers reported learning about soil erosion from the scientists working in Yingtan Station. This happened via their collaboration, e.g. renting the farmlands as field sites and hiring the farmers to help with fieldwork.

\section{The farmer's perspectives on the value of learning from different groups}

Both county groups of farmers showed strong recognition and trust of the farming knowledge passed by generations, which was a long-standing traditional learning method (Figure 12). Most of the farmers in both counties suggested that family knowledge was 'mostly helpful' to them (Figure 12a), with only a small percentage of the groups indicating that such knowledge was 'often', 'sometimes' or 'occasionally' helpful.

Figure 12 Do you think the farming knowledge from the (a) family and (b) government is helpful? Note that the responses in (a) were from $75 \%$ of 114 Yujiang farmers, and $100 \%$ of 40 Puding farmers, and in (b) were only $25 \%$ from Yujiang and $70 \%$ from Puding.

When asked about the farming knowledge from the local government, $75 \%$ and $30 \%$ of the farmers in Yujiang and Puding respectively did not provide responses, and this may be due to farmers not having such a learning experience, or they simply preferred not to comment. However, among those who learned farming from the government sources, more than half of them suggested farming knowledge from their government was 'mostly helpful', followed by being 'sometimes helpful' ( $11 \%$ and $25 \%$ in Yujiang and Puding respectively).

The following is an example of the farmer's perspective of farming knowledge from their family and government in Puding. In addition to their great trust on traditional family knowledge, it also shows that farmers thought positively about the knowledge taught by the government, regardless of whether they had the access to this learning process.

Interviewer: Who did you learn farming from?

Farmer1: Elders would teach children when they started to learn farming from a young age. It is a tradition that elders teach the children and guide them strictly if they cannot perform farming practice well.

Interviewer: Did your children learn farming from you in a same way?

Farmer1: Yes, they did.

Interviewer: Do you think farming knowledge from your family and friends is helpful?

Farmer1: Definitely!

Interviewer: Do you think the farming knowledge from the local government is helpful?

Farmer2: Yes, it is helpful. It is, of course, because the knowledge is useful that the government would like to promote it.

\section{Existing training for productive farming}

There were still many farmers in both counties who did not receive financial support or training from the local government, although the percentage of such farmers was smaller in Yujiang (46\%) than Puding (71\%) (Figure 13). In total, 47\% of the surveyed Yujiang farmers reported receiving financial support from the government and only $24 \%$ in Puding. However, farmers in both counties reported that they received little training: only 10\% in Yujiang and 13\% in Puding. 


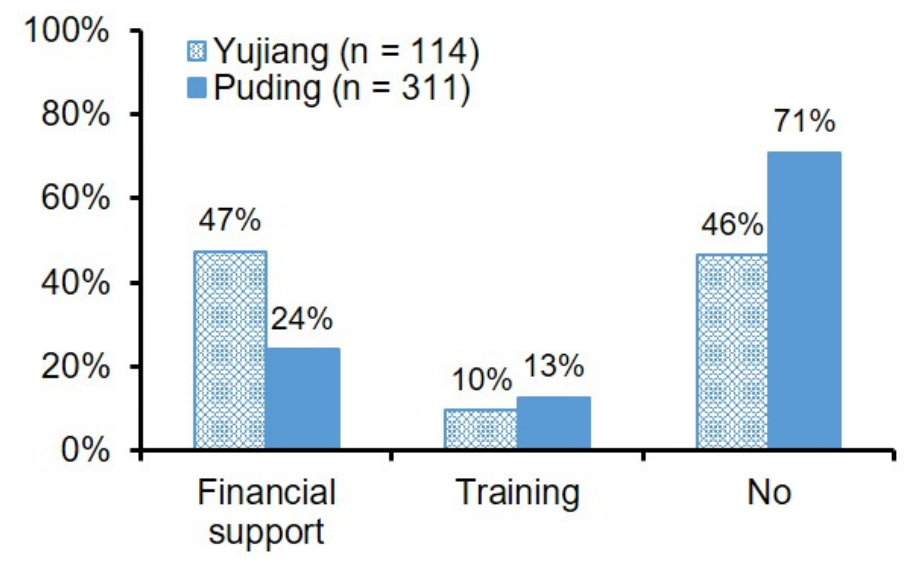

Figure 13 Have you ever received training or financial support from the government before? If yes, what kind of support have you been given? (circle all that apply)

While the village leaders have the most direct interact with their villagers, and farmers would turn to them for help when coming across farming problems, village leaders were concerned as they themselves did not have enough knowledge and technique support for their farmers, and it was difficult to get the support from a higher-level government too.

Village leader1: I think it's needed (to have a direct and routine communication with the scientists). As far as I know, it is really difficult for those farming households in our village to find someone for guidance when they have problems with their farms, for example when the crops and vegetables have a disease. As the village leaders, we will go and ask the relevant departments in the town. But sometimes you can get the help but sometimes not. Therefore, it's nearly absent regarding to the technical support.

In the interview with one of the town leaders in Puding, they suggested that more farming training had been provided to the farmers and leaders in the past two years. However, one of the problems faced was that there was largely more demand for training from the farmers and village leaders than could be offered by the town government currently. Furthermore, only a certain number of training spaces were distributed to the town level and even fewer in each of the villages.

Town leader1: ...... Both farmers and village leaders have been arranged to attend the training. But I have to say the available spaces provided are not enough. For example, in our office, only three spaces are available for us to have training for leek sprout growing while there are six villages (in our authority) conducting this farming. This increases extra workload to provide guidance for all the villages.

...... The county should also provide more training opportunities for each village...... We have eleven villages in our town but (for example) they (the county) only offer seven spaces for training......

\section{Question Area 4: Learning/sharing preference}

Farm visits are the most favoured learning method by the farmers in both counties (Figure 2). However due to the limited training resources (e.g. time and costs), it is difficult to arrange frequent farm visits by the experts/scientists for direct communication about farming. In order to increase the training efficiency for the farmers, we wondered if having farmer representatives might be an alternative and 
easier way to deliver KE. In the March follow-up interviews, we asked both farmers and leaders in Puding county where mixed responses were received regarding this KE method (Figure 144). Many of them recognised it was more practical and convenient to deliver knowledge by having farmer representatives, as the training resources (e.g. funding and trainers) may only be available for a small number of farmers. Additionally, it would provide an easier access for the farmers to approach and seek for help when there was a local experienced farmer in their own village. However, some concerns about this approach were raised during the interviews (described in section 3.3).

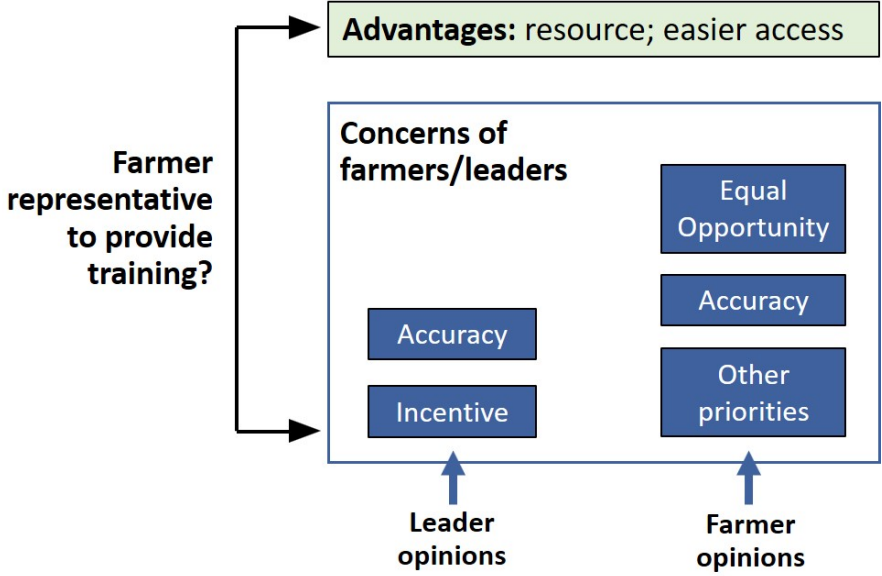

Figure 14 The advantages of having farmer representatives to help deliver shared farming knowledge, and the concerns from the leaders and farmers of this KE method. The understanding was summarised according to the interview in Puding county.

The following are examples to show the various perspectives of farmers and leaders on having farmer representatives for knowledge learning and exchanging.

\section{- The perspectives of the farmers in Puding}

Interviewer: Do you prefer having training courses together with all the other farmers, or that we train the village leaders (as farmer representatives) first who then can teach you all?

Farmer1: [Train] the group leaders [as farmer representatives] first... In our village, there are a few people quite proactive in this [training participation]. They are good at managing [for training preparation] and pay attention to it. It is good to select and train a few people first... It is more effective to train those who are more experienced in farming.

Farmer2: It is better to train the farmers all together. Some people are not willing to share with you about what they learn [if only train the farmer representatives] ... Those who are selected for training may not talk about it if they become arrogant... They may share with those who are close to them...So it's better to provide the training to all the farmers like a group meeting and inform the training event via the public speaker in the village.

\section{- The perspectives of the leaders in Puding}

Interviewer: Is there any agrotech officer in your village?

Village leader1: We very much need this kind of people in the village, but there is none......As far as I know there are agrotech officers in the town, but they do not provide guidance in the villages...... because they have much workload [as many villages in one town].

Interviewer: About training, do you think it should be organised for all the farmers together, or provided for a few in particular who then can help disseminate the knowledge [to other farmers]? 
Village leader1: Train a few farmers first... One can teach ten more. It's not practical to call in all the farmers thinking of the training venues and costs. But if to train a few first, they can help disseminate [the knowledge] and encourage other farmers [to learn]. This is better.

Village leader2: Training for all the farmers together. It [the knowledge] will be clearer from you [the professionals] directly. If just train one or two farmers, they cannot explain it well... as they (the trained farmers) are not well educated enough [to fully understand the knowledge before disseminating].

Town leader1: We do have these [farmer representatives]. Take the leek sprout planting for instance, it is impossible to provide training to a wide range. That will be too much people. In the early March, we sent two farmers to attend this training. They have become as two technicians and can teach the leek farmers in the villages about planting and farm management... [These two people were selected] as they grew the leek sprouts before and have some experience. It will be difficult with no such experience at all..... [The payment for the technicians] was arranged by the county government.

I think the training organised by the county... should focus on the key farmers (referring to e.g. targeted farmers for poverty alleviation) and the leading farmers (similar to our farmer representatives) ... As the town leaders, we cannot always be there every time when the problem occurs. Thus if there are such leading farmers in the villages, they can follow on [and help] with the farming issues.

Online resources cited:

1. Government news from Yingtan City in 2017: “全国首个稻渔综合种养院士工作站 在鹰潭市挂 牌成立 (The first academician workstation for rice-fishing cultivation in the country established in Yingtan City)". http://www.ytnyj.gov.cn/yzy xb/yyyz xb/201712/t20171204_446558.htm. Last accessed: $04 / 12 / 2018$

2. China's proposal for poverty reduction and development. Speech by Deputy Director General of the IPRCC at 2017 China Poverty Reduction International Forum. https://ophi.org.uk/wpcontent/uploads/1.-Dr.-Tan.pdf. Last accessed: 04/12/2018 